\title{
Profile of Morphology Teachers in Chilean Universities
}

\author{
Perfil de los Docentes de Morfología en Universidades Chilenas
}

\author{
Emilio Farfán ${ }^{1}$; Julio Cárdenas²; Omar Espinoza-Navarro³ ${ }^{3}$ Pablo A. Lizana \\ Juan Pacheco ${ }^{5}$; Paulo Salinas ${ }^{6}$; Andrés Riveros ${ }^{7} \&$ Mauricio Villarroel $^{8}$
}

\begin{abstract}
FARFÁn, E.; CÁRdenAS, J.; ESPINOZA-NAVARRO, O.; LIZANA, P. A.; PACHECO, J. ; SALINAS, P.; RIVEROS, A. \& VILLARROEL, M. Profile of morphology teachers in Chilean universities. Int. J. Morphol., 39(6):1615-1624, 2021.

SUMMARY: University teaching in Chile has been influenced in recent decades by changes to the education system, which has increased universities and academic offerings and, therefore, the demand for new instructors. Teaching morphological sciences has not been exempt from these changes, with new instructors needed to fill the growing offerings of programs that include anatomy, embryology and histology. The aim was to understand the profile of the academics teaching morphology in Chile in 2020. A voluntary online survey was applied to 213 university morphology teachers, in which information was collected on professional and academic training, geographical distribution, gender, continuing academic education and employment situation. Overall, the results show that $65.9 \%$ of instructors were men and $35.1 \%$ women, and most (34.6\%) had between 5 and 10 years in morphology, and a master's degree was predominant (53.27 \%). In the area of anatomy, $46 \%$ of instructors were physiotherapists and $24.6 \%$ dentists, whereas in the areas of histology and embryology, the group was diverse. In terms of employment, $49.06 \%$ stated they worked full time, mainly in teaching. $41.31 \%$ of the instructors were concentrated in the Metropolitan Region. There was no association between gender and graduate training, maximum academic degree attained, type of workday or academic profile, but there was one by disciplinary area. The conclusion drawn is that morphology teachers in Chilean universities are part of a wide range of professionals dedicated to different disciplinary areas, with master's degree and/or specialization, located mainly in the Metropolitan Region. This multidisciplinary profile demonstrates the mainstreaming of morphology teaching in Chile.
\end{abstract}

KEY WORDS: Teaching; Morphology; University; Chile.

\section{INTRODUCTION}

Teaching morphology in Chile is primarily associated with the development of anatomy, which dates from the end of the 16th century (Cárdenas, 2017). In 1842, the School of Medicine of the National Institute was incorporated into the recently created University of Chile, with such eminent professors as José Joaquín Aguirre, Lafargue and Padín. Due to the scant supply of morphology training in the country, it was customary at the time to send young physicians to Europe to study, among them David Benavente in anatomy and Vicente Izquierdo in histology (Cárdenas, 2020).

As the country progressed, morphology-related contents expanded with the development of new universities.
In them, the study of anatomy, histology and embryology was included in the first two years of medical studies. At that time academics dedicated to morphology derived mainly from two professions: doctors and dentists. They were mainly dedicated to this work full time or alternated their work with clinical activities (Osorio et al., 2020). The ensuing decades would see a boom in morphology research and teaching, where the contributions by the "Masters of Anatomy" Gustavo Girón, Adolfo Escobar, Enrique Solervicens and Abraham Wainstein would be prominent. These professors trained a group of 35 academics who in 1938 founded the Society of Normal and Pathological Anatomy, which was dissolved in 1970 (Rodríguez \& Cárdenas, 2017). Later in

\footnotetext{
${ }^{1}$ Departamento de Anatomía, Escuela de Medicina, Pontificia Universidad Católica de Chile, Santiago, Chile. https://orcid.org/0000-0002-8819-2945

${ }^{2}$ Departamento de Anatomía y Medicina legal, Facultad de Medicina, Universidad de Chile. https://orcid.org/0000-0002-4604-0783

${ }^{3}$ Departamento de Biología, Facultad de Ciencias, Universidad de Tarapacá, Arica-Chile. https://orcid.org/0000-0002-2666-8725

${ }^{4}$ Laboratory of MorphologicalSciences, Instituto de Biología, Pontificia Universidad Católica de Valparaíso, Valparaíso 2373223, Chile. https://orcid.org/ 0000-0002-9366-6930

${ }^{5}$ Departamento de Ciencias Morfológicas, Facultad de Medicina y Ciencia, Universidad San Sebastián, Lago Panguipulli 1390, Puerto Montt 5501842, Chile.

${ }^{6}$ Laboratorio de Morfología Animal \& Experimental, Instituto de Biología, Pontificia Universidad Católica de Valparaíso, Valparaíso 2373223, Chile. https:/ /orcid.org/0000-0003-2273-0904

${ }^{7}$ Departamento de Ciencias Morfológicas, Facultad de Medicina y Ciencia, Universidad San Sebastián, Lientur 1457, Concepción 4080871, Chile.

${ }^{8}$ Laboratorio de Morfología, Departamento Disciplinario de Biología, Universidad de Playa Ancha, Valparaíso, Chile. https://orcid.org/0000-0002-0953-9294 All authors contributed equally in the conception, writing and final editing of the manuscript.
} 
1979, the current Chilean Society of Anatomy (SChA) was founded, an entity that draws together the morphologists of Chilean universities (Cárdenas \& Rodríguez, 2018).

Chilean higher education underwent significant changes starting in the 1980s. One of these was the enactment of the General Higher Education Law in 1981, which created 11 private universities and also dissolved the network of public universities existing up to that point. In 1990 the Constitutional Organic Law of Education (LOCE) (Law 18.962) was enacted, creating 29 new universities which were able to gain economic and administrative autonomy (Cruz-Coke,2004). As a result of these changes, total undergraduate enrollment in Chile in 2020 was 1,144,184 students, of which 319,479 were in first year (Consejo Nacional de Educación, 2020). With respect to the academic offering for 2020, of the 55 Chilean universities, 51 had at least one of the 16 programs with courses in morphology. This amounts to 673 programs with morphology contents (Departamento de Evaluación, Medición y Registro Educacional, 2020). By virtue of a lack of knowledge about the profile of the morphology teacher due to the changes in university education, and based on the exponential increase in programs which require teaching of the morphological disciplines, this study was conducted to learn about the professional profile of the academics teaching in the areas of morphological sciences in Chile in 2020.

\section{MATERIAL AND METHOD}

Survey. The study consisted of the application of a survey prepared on the basis of 13 multiple choice questions with a range of responses that collected data on professional and academic training, sociodemographic characteristics, geographical distribution, gender, continuing academic education and employment situation. The participants were contacted via e-mail using the SChA database, website and social networks (Facebook ${ }^{\circledR}$ and Instagram $\left.{ }^{\circledR}\right)$. These communication channels made possible the development of snowball sampling (Heckathorn, 2011), a non-probability method where the participants contribute by recruiting new participants. 512 contacts were obtained this way, of which 213 agreed to participate, responding to the instrument online (Google Forms; Google LLC, Mountain View, California, USA)

Data and statistical analysis. The data collected were ordered in Microsoft®Excel tables for MacOS (v.16.43, Microsoft ${ }^{\circledR}$ Corporation) and then exported to GraphPad Prism9.0 for MacOS(v9.1.0. GraphPadSoftware, La Jolla, California USA) to generate descriptive statistics. The data were ordered in contingency tables using a chi-squared test to evaluate the association between gender and the attainment of graduate degrees, doctorates, the type of workday, disciplinary area and academic profile. Additionally, the relation was sought between SChA membership and years of teaching experience. For the variables related to the geographical distribution of the academics, macrozones of the Chilean Ministry of Science, Technology, Knowledge and Innovation were used (Agencia Nacional de Investigación y Desarrollo, 2021). The statistical significance for the hypothesis test was $\mathrm{p}<0.05$.

\section{RESULTS}

213 surveys were answered in full (42\% of the sample), which signified instructors from 36 Chilean universities ( $70.6 \%$ of the sample). With respect to the representativeness, the respondents belonged to the universities of the Council of Rectors of Chilean Universities (CRUCH) (52.1\%), and private universities included (36.2 $\%)$ and not included $(11.7 \%)$ in the Single Admission System. Anatomy and neuroanatomy were the predominant morphological disciplines in Chile. Of all the respondents, $46.26 \%, 5.14 \%, 1.87 \%$ and $0.93 \%$ stated they participated in particular in anatomy, histology, neuroanatomy and embryology, respectively (Table I). The results obtained by gender, last degree obtained, continuing education, type of workday, academic profile and years of academic experience are described in Figure 1. With respect to the professions, the following predominated: i) physiotherapists and dentists in anatomy, ii) veterinarians and biologists in histology, and iii) biochemists and midwives in embryology (Table II). In

Table I. Distribution of the morphological disciplines.

\begin{tabular}{ll}
\hline Discipline(s) & $\mathrm{n}(\%)$ \\
\hline Anatomy & $99(46.26)$ \\
Anatomy/Neuroanatomy & $45(21.03)$ \\
Histology/Embryology & $11(5.14)$ \\
Histology & $11(5.14)$ \\
Anatomy/Neuroanatomy/Histology/Embryology & $6(2.80)$ \\
Anatomy/Neuroanatomy/Embryology & $6(2.80)$ \\
Biology & $5(2.34)$ \\
Anatomy/Histology/Embryology & $5(2.34)$ \\
Anatomy/Histology & $5(2.34)$ \\
Neuroanatomy & $4(1.87)$ \\
Anatomy/Biology & $4(1.87)$ \\
Histology/Embryology/Biology & $3(1.40)$ \\
Anatomy/Neuroanatomy/Histology & $3(1.40)$ \\
Anatomy/Embryology & $3(1.40)$ \\
Embryology & $2(0.93)$ \\
Histology/Biology & $1(0.47)$ \\
Anatomy/Histology/Biology & $1(0.47)$ \\
\hline
\end{tabular}


A
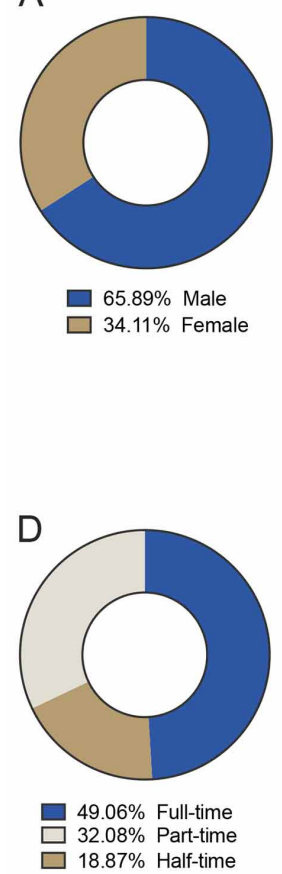

$\mathrm{B}$

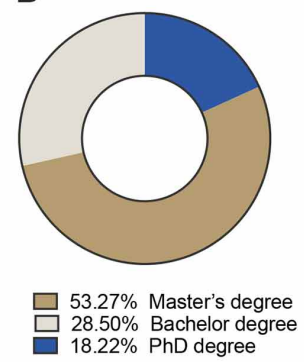

$\mathrm{E}$

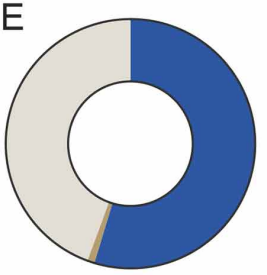

$54.67 \%$ Teacher

$44.39 \%$ Teacher/Research $0.93 \%$ Research

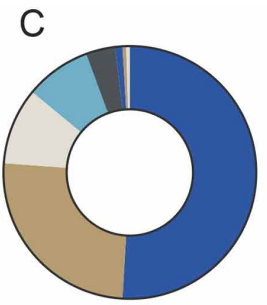

$50.93 \%$ Cont. Educ. Certific $25.23 \%$ None $9.81 \%$ Specialist

$8.41 \%$ Cont. Educ. Certific./Specialist

$3.74 \%$ Postdoct.

$0.93 \%$ Postdoct./Cont. Educ. Certific./Specialist.

$0.47 \%$ Postdoct./Specialist

$\square 0.47 \%$ Postdoct./Cont. Educ. Certific./Specialist.

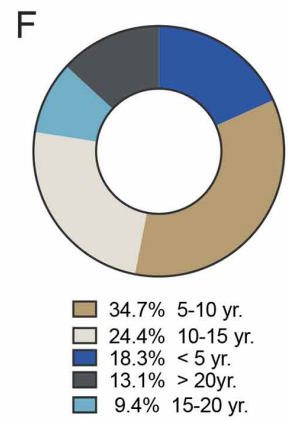

Fig. 1. Sociodemographic and academic characteristics of the teachers who taught morphology in Chile in 2020. (A) gender, (B) last academic degree obtained, (C) continuing education, (D) type of workday, (E) academic profile and $(\mathrm{F})$ years of experience of academics who taught morphology in Chile in 2020 $(\mathrm{n}=213)$.

Table II. Percentage distribution of morphological disciplines by profession in Chile.

\begin{tabular}{|c|c|c|c|c|c|c|}
\hline & Anatomy & Histology & Embryology & $\begin{array}{c}\text { Histology- } \\
\text { Embryology }\end{array}$ & Biology & $\begin{array}{l}\text { Histology- } \\
\text { Biology }\end{array}$ \\
\hline $\mathrm{BIOL}$ & 2.1 & 23.1 & 0.0 & 27.8 & 25.0 & 100.0 \\
\hline BIOC & 0.5 & 0.0 & 50.0 & 0.0 & 25.0 & 0.0 \\
\hline NRS & 1.1 & 7.7 & 0.0 & 0.0 & 0.0 & 0.0 \\
\hline ST & 1.6 & 0.0 & 0.0 & 0.0 & 0.0 & 0.0 \\
\hline PHY & 46.0 & 0.0 & 0.0 & 0.0 & 0.0 & 0.0 \\
\hline MIDW & 0.5 & 0.0 & 50.0 & 16.7 & 0.0 & 0.0 \\
\hline $\mathrm{MD}$ & 8.0 & 7.7 & 0.0 & 0.0 & 0.0 & 0.0 \\
\hline DVM & 7.0 & 23.1 & 0.0 & 16.7 & 0.0 & 0.0 \\
\hline DEN & 24.6 & 15.4 & 0.0 & 16.7 & 0.0 & 0.0 \\
\hline TCHR, BIO & 2.7 & 7.7 & 0.0 & 11.1 & 50.0 & 0.0 \\
\hline TCHR, PE & 1.6 & 0.0 & 0.0 & 0.0 & 0.0 & 0.0 \\
\hline MT & 3.7 & 15.4 & 0.0 & 11.1 & 0.0 & 0.0 \\
\hline OTHER & 0.5 & 0.0 & 0.0 & 0.0 & 0.0 & 0.0 \\
\hline
\end{tabular}

Abbreviations: BIOL, Biologist; BIOC, Biochemist; NRS, Nurse; ST, Speech Therapist; PHY, Physiotherapist; MIDW, Midwife; MD, Physician; DVM, Veterinarian; DEN, Dentist; TCHR, BIO, Biology Teacher; TCHR, PE, Physical Education Teacher; MT, Medical Technologist.

Table III. Percentage distribution of professions that teach morphology in Chile according to discipline ( $\mathrm{n}=213)$.

\begin{tabular}{|c|c|c|c|c|c|c|c|c|c|c|c|c|c|}
\hline & $\begin{array}{l}\text { BIOL } \\
\text { (n 14) }\end{array}$ & $\begin{array}{l}\text { BIOC } \\
(n \text { 3) }\end{array}$ & $\begin{array}{l}\text { NRS } \\
\text { (n 3) }\end{array}$ & $\begin{array}{l}\mathrm{ST} \\
(\mathrm{n} \mathrm{3)})\end{array}$ & $\begin{array}{l}\text { PHY } \\
(\mathrm{n} 86)\end{array}$ & $\begin{array}{l}\text { MID } \\
\text { (n 5) }\end{array}$ & $\begin{array}{l}\text { MD } \\
\text { (n 16) }\end{array}$ & $\begin{array}{l}\text { DVM } \\
\text { (n 19) }\end{array}$ & $\begin{array}{l}\text { DEN } \\
(\mathrm{n} 51)\end{array}$ & $\begin{array}{l}\text { TCHR, } \\
\text { (n 10) }\end{array}$ & $\begin{array}{l}\text { TCHR, PE } \\
\text { (n 3) }\end{array}$ & $\begin{array}{l}\text { MT } \\
\text { (n 11) }\end{array}$ & $\begin{array}{l}\text { OTHE } \\
\text { (n 1) }\end{array}$ \\
\hline Ana & 28.6 & 33.3 & 66.7 & 100.0 & 100.0 & 20.0 & 93.8 & 6 & 90.2 & 50 & 100.0 & 63.6 & 100.0 \\
\hline Histology & 21.4 & 0.0 & 33.3 & 0.0 & 0.0 & 0.0 & 6.3 & 15.8 & 3.9 & 10.0 & 0.0 & 18.2 & 0.0 \\
\hline Embryology & 0.0 & 33.3 & 0.0 & 0.0 & 0.0 & 20.0 & 0.0 & 0.0 & 0.0 & 0.0 & 0.0 & 0.0 & 0.0 \\
\hline Histology-Embryology & 35.7 & 0.0 & 0.0 & 0.0 & 0.0 & 60.0 & 0.0 & 15.8 & 5.9 & 20.0 & 0.0 & 18.2 & 0.0 \\
\hline Biology & 7.1 & 33.3 & 0.0 & 0.0 & 0.0 & 0.0 & 0.0 & 0.0 & 0.0 & 20.0 & 0.0 & 0.0 & 0.0 \\
\hline Histology-Biology & 7.1 & 0.0 & 0.0 & 0.0 & 0.0 & 0.0 & 0.0 & 0.0 & 0.0 & 0.0 & 0.0 & 0.0 & 0.0 \\
\hline
\end{tabular}

Abbreviations: BIOL, Biologist; BIOC, Biochemist; NRS, Nurse; ST, Speech Therapist; PHY, Physiotherapist; MIDW, Midwife; MD, Physician; DVM, Veterinarian; DEN, Dentist; TCHR, BIO, Biology Teacher; TCHR, PE, Physical Education Teacher; MT, Medical Technologist. 
Table IV. Association between graduate degree and macrozones, including the Metropolitan Region, Chile.

\begin{tabular}{llll}
\hline Macrozonea & $\begin{array}{l}\text { Graduate } \\
\text { degree }^{\mathrm{b}}\end{array}$ & $\begin{array}{l}\text { Bachelor's } \\
\text { degree }\end{array}$ & Total \\
\hline North & $10(6.58)$ & $0(0)$ & $10(4.69)$ \\
Central & $18(11.84)$ & $10(16.39)$ & $28(13.15$ \\
Southern-Central & $34(22.37)$ & $13(21.31)$ & $47(22.07$ \\
Southern & $31(20.39)$ & $5(8.20)$ & $36(16.90$ \\
Austral & $4(2.63)$ & $0(0)$ & $4(1.88)$ \\
Metropolitan & $55(36.18)$ & $33(54.10)$ & $88(41.31$ \\
\hline
\end{tabular}

Data presented in frequency and percentage $\mathrm{n}(\%)$, Fisher's exact test, $\mathrm{p}<0.015$. a Macrozones according to the Chilean Ministry of Science, Technology, Knowledge and Innovation, bGraduate degree: $\mathrm{PhD}$ and/or Master's.

Table V. Association between $\mathrm{PhD}$ and Macrozones, including the Metropolitan Region, Chile.

\begin{tabular}{llll}
\hline Macrozone a & PhD & $\begin{array}{l}\text { Master's/B } \\
\text { achelor's } \\
\text { degree }\end{array}$ & Total \\
\hline North & $6(15.38)$ & $4(2.30)$ & $10(4.69)$ \\
Central & $3(7.69)$ & $25(14.37)$ & $28(13.15)$ \\
Southern-Central & $5(12.82)$ & $42(24.14)$ & $47(22.07)$ \\
Southern & $9(23.08)$ & $27(15.52)$ & $36(16.90)$ \\
Austral & $2(5.13)$ & $2(1.15)$ & $4(1.88)$ \\
Metropolitan & $14(35.90)$ & $74(42.53)$ & $88(41.31)$ \\
\hline
\end{tabular}

Data presented in frequency and percentage n (\%), Fisher's exact test, $\mathrm{p}<0.015$. a Macrozones according to the Chilean Ministry of Science, Technology, Knowledge and Innovation.

addition, the evidence indicated that physiotherapists, speech therapists and physical education teachers worked exclusively in anatomy. By contrast, biology and science teachers stated they taught not only anatomy, but also histology, histology-embryology, embryology and biology (Table III). With respect to geographical distribution according to the macrozones and Metropolitan Region, there was a significant association with having a graduate degree ( $p<0.015$; Table IV) and a doctorate ( $p<0.005$; Table V). The Metropolitan Region had the highest proportion of instructors with graduate degrees (36.18\%), master's degrees (42.53 $\%)$ and doctorates $(35.90 \%)$. They were concentrated in Santiago $(41.3 \%)$, the Valparaíso-Viña del Mar conurbation $(14.1 \%)$ and Concepción (12.2\%; Fig. 2). Regarding the association of variables (Fig. 3), no association was detected between gender and having a graduate degree $(\mathrm{A} ; \mathrm{p}=0.44)$, the academic degree of doctor $(\mathrm{B} ; \mathrm{p}=0.81)$, type of workday $(C ; p=0.29)$ or the stated academic profile $(E ; p=0.40)$. However, significant associations were found between gender and the morphological discipline $(\mathrm{D} ; \mathrm{p}=0.001)$ and between SChA membership and years of teaching experience (F; $\mathrm{p}<0.001)$.

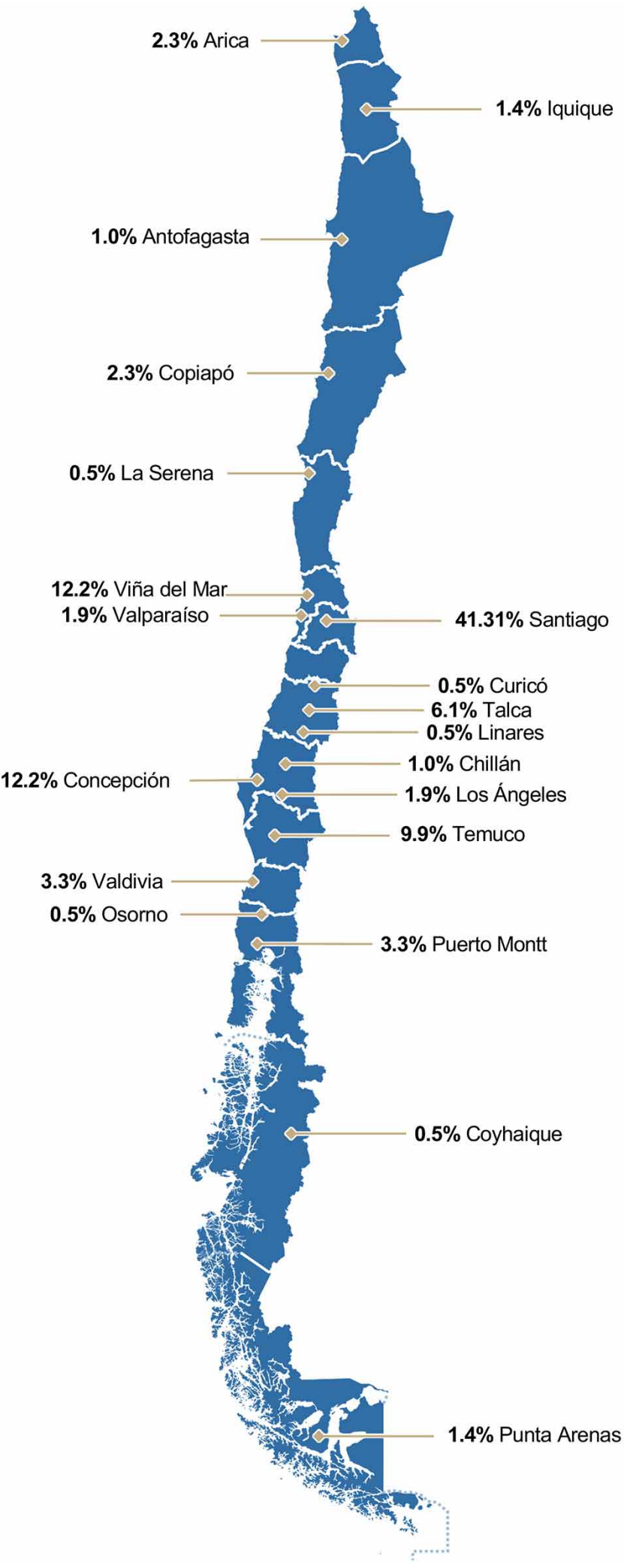

Fig. 2. Percentage geographical distribution of academics who taught morphology in Chile in 2020 according to city where the work is performed $(n=213)$. 

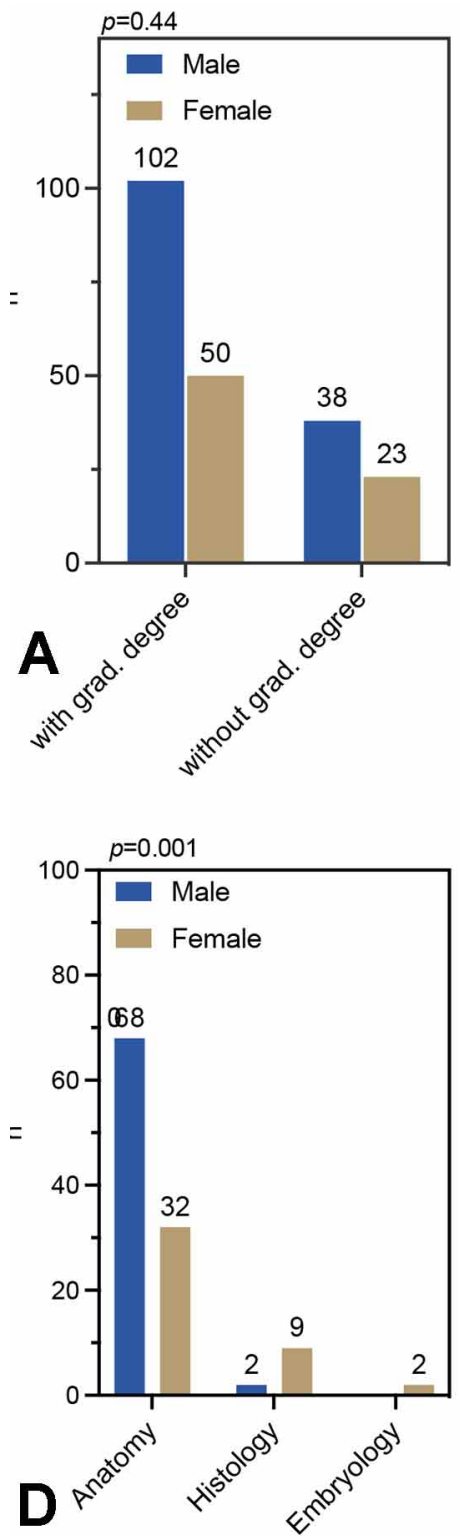
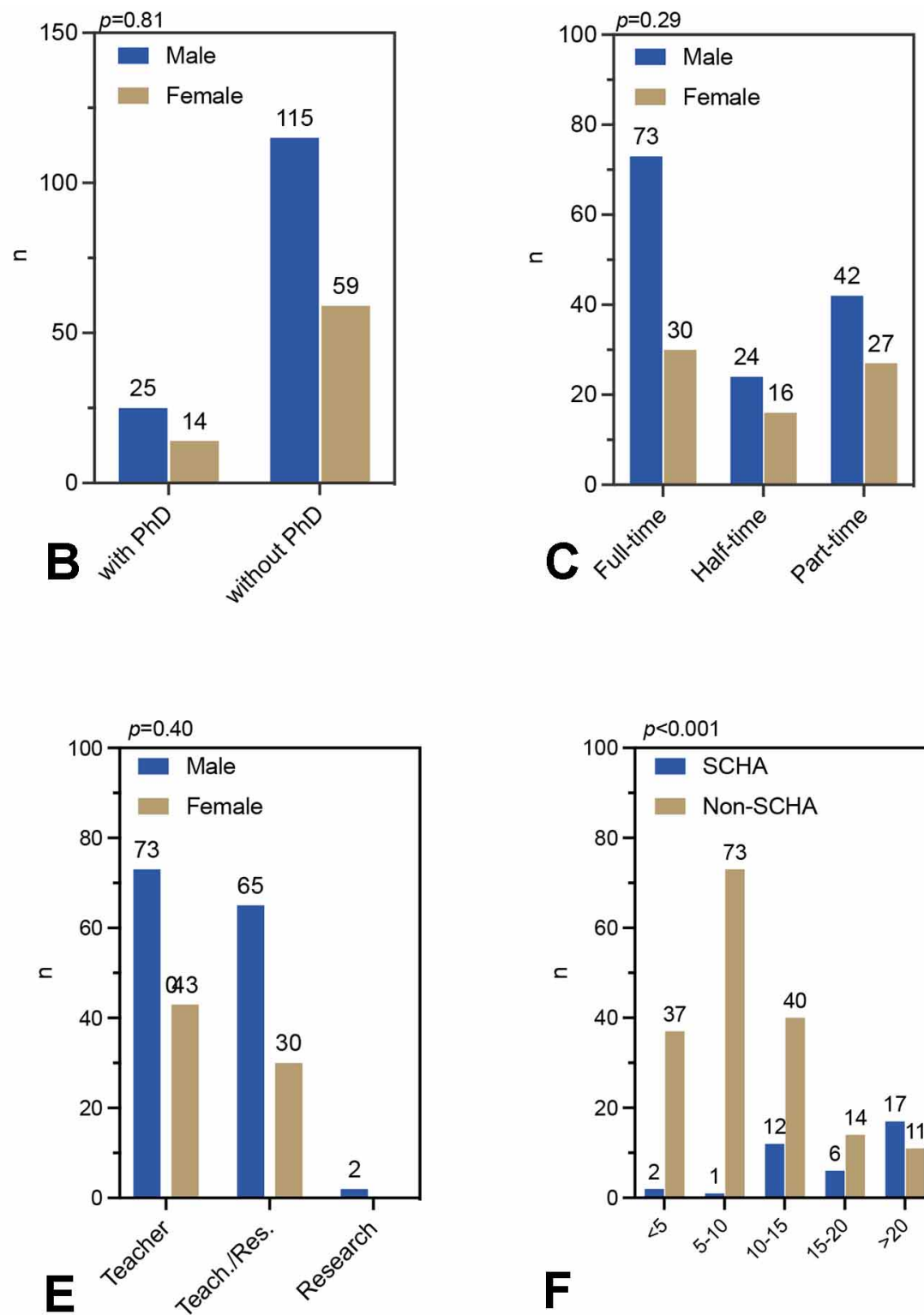

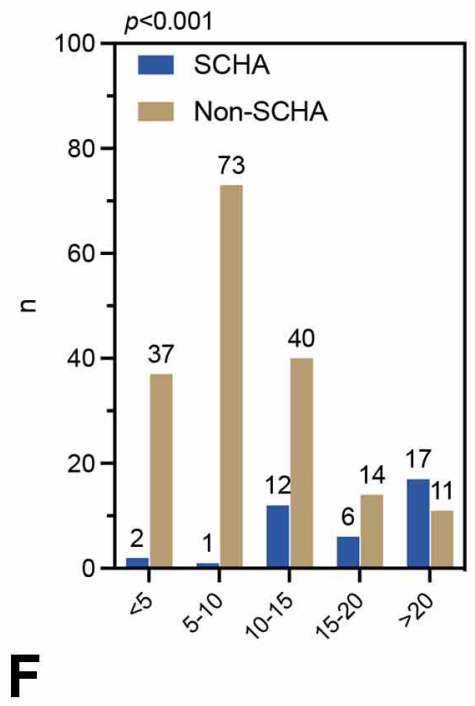

Fig. 3. Association between the variables gender and (A) attaining graduate degrees, (B) $\mathrm{PhD}$, (C) type of workday, (D) exclusive dedication to a discipline and (E) type of academic profile declared.Profile of members of the Chilean Society of Anatomy and morphology teachers ordered by years of experience. Additionally, $(\mathrm{F})$ describes the relation between SChA membership and years of teaching experience.

\section{DISCUSSION}

This study is the first to describe the sociodemographic and academic characteristics of professionals teaching morphology in Faculties of Sciences, Health Sciences, Veterinary Medicine and Medicine in Chile.

This study confirms that 512 instructors were dedicated to morphology in 2020 in Chile, which contrasts with the 100 instructors of the SChA at the time of its foundation, understanding that this was not necessarily the full complement of teachers during that period. This substantive change in the population of morphologists could be a response to the increasing demand for undergraduate and graduate programs that include morphological sciences in the curriculum, to the high academic credentials of gene- 
ral anatomy courses, and to the academic offerings of continuing education programs that most Chilean universities provide. Some studies report a global trend in this respect (Kagan, 2002; Khan, 2007; Kramer et al., 2008; Johnson et al., 2012), declaring an increase in the number of instructors per course, in the demand for academic specialization and in the course offerings.

It was observed that anatomy and neuroanatomy were predominant in terms of the disciplines. A myriad of factors consistent with studies published in other countries (interest, professional development, academic position, labor supply, numerous courses, etc.) would explain this situation. Nevertheless, one worrisome aspect is what is happening with embryology. Fewer than $1 \%$ of the respondents stated they were an embryologist in particular. The respondents who stated they worked in this subject indicated that embryology was taught, generally, along with other basic science subjects. $5.1 \%$ taught embryology along with histology, $2.8 \%$ with anatomy and neuroanatomy, $2.3 \%$ with anatomy and histology, $1.4 \%$ with histology and biology and $1.4 \%$ with anatomy. As far as whether embryology was taught as a separate course, only $0.93 \%$ answered yes. Of all the respondents, $13 \%$ reported that embryology was taught along with another discipline, and of all the instructors who participated in embryology, only $6.6 \%$ stated they taught it as a separate subject. This situation was described by Carlson (2002), who indicated that for some reason embryology, more than most other disciplines in basic medical sciences, has had problems in recent decades finding a comfortable niche within the medical studies syllabus or in the sciences. This could be related to the explosion of developmental biology that began at the beginning of the 1990s, where educators faced the dilemma of how much of the "new" and "old" embryology must be presented to students, and if it should be done in a molecular, histological or anatomical context.

With respect to the professional profile, this study demonstrates that anatomy is currently taught mainly by physiotherapists and dentists. The situation for histology and embryology is different, where veterinarians, biologists, biochemists and midwives are frequent. This change in the profile could be related to the increase in the number of professionals from other programs, to the curricular training of each profession, and in the case of physicians to the development of their clinical training. This provides evidence of the current mainstreaming of the morphological sciences and the broad range of professionals currently teaching in them.

Another change scenario in national morphology teaching has been academic training. Although physicians predominated in the anatomy professorships during the 20th century (Cárdenas, 2017), they lacked graduate training and formal teacher training. Nowadays, most Chilean morphology teachers have received graduate training in master's programs, as well as specific teacher training in certificate programs. This has been concomitant with academic strengthening programs particularly in the teaching areas that Chilean universities have implemented across the board in recent years (e.g., certificates in education, teaching, or ICTs). The role of teacher training in classroom teaching performance has been widely recognized by the Anatomical Society of Great Britain and Ireland and the American Association for Anatomy, who have developed a specific training program in the area, not only enhancing disciplinary training, but also teacher training (Fraher \& Evans, 2009; Lachman et al., 2013). In Chile, such practices have enabled university instructors not only to improve their knowledge in the morphological disciplines, but also to acquire the skills necessary to teach them and to become involved in research. Another interesting aspect of evidence of change is that morphologists used to have to specialize abroad; however, in Chile today there are graduate academic offerings: both master's and doctoral programs in morphological sciences, as well as certificate and continuing education programs. The results indicate that $28.5 \%$ of the respondents have a bachelor's degree, $53.3 \%$ a master's degree and $18.2 \%$ a doctorate (Fig. 1B), results that differ from what is reported in the "UCHILE Institutional Directory 2019", where with respect to overall academic training, $27.8 \%$ had a bachelor's degree, $18.7 \%$ a master's and $36.2 \%$ a doctorate (Universidad de Chile, 2019). Contrasting these figures highlights the difference among those who have a master's degree, which could be attributed to job competitiveness in the morphology field, which demands that professionals obtain graduate training; however, the percentage of morphologists with a doctorate is lower than the national average. Although the explanation may be multifactorial, in Chile health programs linked to private universities included or not in the Single Admission System, given their eminently teaching nature, may not generally consider it imperative to have professors with a doctorate.

In work environment, it was observed that $49.1 \%$ of the respondents work full time, $18.8 \%$ half days and 32.1 $\%$ part time (Fig. 1D) compared to the national results, which indicate $41.6 \%$ work full time, $13 \%$ half days and $45.4 \%$ part time and per hour (Universidad de Chile). It is important to state that $53 \%$ of the instructors surveyed had $<10$ years in morphology (Fig. 1F). This background demonstrates that morphology teachers are in the main academically young, as is reflected in the years of educational experience and academic degrees. This suggests an academic profile associated with a high interest in academic positions and/or 
the search for further education. It is worth noting that most morphology teachers work in universities belonging to the Council of Rectors of Chilean Universities (CRUCH). Although CRUCH universities offer programs that require anatomical knowledge, the number of private universities included in the Single Admission System is relatively lower than the number of faculties, schools or departments in accredited schools (CRUCH). So much so that the morphologists belonging to any of the CRUCH universities presented greater experience (years of practice) and high academic degrees $(\mathrm{PhD})$; therefore, they have more training potential than young teachers, especially from private universities or other institutions. Levy (2014) and Atanda (2017) described such mentoring as resulting in benefits and profound implications for the transfer of knowledge and scientific productivity of young academics. These interactions would generate more opportunities for immediate and future collaborations.

An interesting result is noted in the surveyed members of the SChA, where there was an association between years of academic experience and membership status, i.e., $61 \%$ of its members declared having $>15$ years of academic experience, representing a reality within scientific societies given the nature and demand of these organizations' admission requirements (Fig. 3F). By contrast, non-member respondents presented a more heterogenous distribution in terms of years of experience. This group contained $82 \%$ of the respondents, which suggests that most morphology teachers in Chile do not join these societies, possibly out of a lack of interest in participating in a scientific society compatible with their disciplinary field or due to the difficulties that arise from being subjected to the admission criteria. This group of non-member academics was considerably diverse in terms of gender, and their characteristics suggest a profile that would provide a constant influx of new talents, abilities and ideas, not only to the SChA, but to the discipline in Chile. The opportunities that membership in a scientific society can offer instructors with little experience have been reported, and these include: making contact with peers, contributing to scientific meetings, conferences, and participating in academic development activities (Kaplan, 2013; Ansmann et al., 2014; Matyas et al., 2017). Given the reality of the results presented in this survey, the SChA will have a key role in the future, since it will have to offer nonmember instructors and researchers motivational instances and opportunities so that peers may interact significantly in morphology-related scientific activities, particularly during the years of undergraduate training, as well as in the initial stages of their academic life. All this should serve as fertile ground for the SChA to be able to persuade, include and retain the next generation of academics who will become leaders in their respective fields.
On academic training, the data collected demonstrated an aspirational academic feature evidenced in the high rates of attaining graduate degrees and qualifications (e.g., master's, doctorates and certificates). In the United States, in a study conducted on morphology teachers, Schaefer et al. (2018) reported that $55 \%$ had the academic degree of doctor, $39 \%$ had a master's degree and $45 \%$ had received some type of post-doctoral training. This contrasts with the situation in the present survey: although $54 \%$ and $45 \%$ of the respondents stated they were a teacher and teacher/researcher, respectively, an interesting case is what occurs with the post-doctorates. In Chile, there are both university and government funding programs that stimulate not only their training, but also their incorporation into academia. However, post-doctoral preparation in Chile is a practice that is still in its early stages in the discipline of morphology. A novel aspect is that teachers exclusively with anatomy and classical training have experienced a decline, giving way to generations with training in morphological research, education and specialization in university teaching. This last point is a growing practice demonstrated in the early lines of research, some examples of which are the incorporation of research into anatomical techniques useful in teaching (Skopnik-Chicago et al., 2020) and the evaluation of team-based learning to study cases that help integrate basic and clinical knowledge (Diamond et al., 2020). This new generation of Chilean morphology teachers merits special attention given the indicators of morphology publications in Web of Science in Latin America. In a review of the publications from 2018-2019, 682 articles were found in the research area "anatomy and morphology", of which Chilean researchers contributed $29 \%$ of the total, being the second country of greatest productivity in Latin America after Brazil (Web of Science, 2021).

Figure 2 provides the geographical distribution of the respondents in the study, where it was observed that Santiago contained $41.31 \%$ of the instructors surveyed, while the Region of Valparaiso had $14.1 \%$ and the Region of Biobío $12.2 \%$. A retrospective view shows that in 2012 in Chile, $55 \%$ of universities were located in the Metropolitan Region, $11.7 \%$ in the Region of Valparaiso and $10 \%$ in the Region of Biobío (Ganga \& Felix, 2012). This situation is consistent with the demographic results obtained in this survey, revealing a relation between labor supply and number of instructors. This suggests that the creation of new universities did not lead to a homogenous development in the geographical distribution of new morphologists; on the contrary, the evidence indicates that it has been centralist with regard to creating new employment opportunities, particularly academic positions with high impact in teaching and the generation of morphological knowledge relevant to the challenges and potentials of a particularly regional environment. 
With respect to the influence of geographical distribution on the chances of continuing graduate studies, our results indicate that the greatest number of instructors with graduate degrees was in the Metropolitan Region, central-south and southern macrozones (Tables IV and V), coinciding with the places where research centers and morphology training programs are located. Of course it is understood that living near a place of study represents an advantage in terms of access over those who live far away, because the latter must resolve economic, work and family situations that represent obstacles to overcome in order to continue with their studies. Accordingly, it is inferred that the geographical location of the anatomist affects their chances for morphology training, thereby reducing the opportunities of those who are in more remote areas.

On a disciplinary level, Tiznado-Matzner et al. (2019) compiled data on 12 anatomy laboratories in Chilean universities that worked with cadaver preparations, of which two are located in the northern macrozone and one in the austral macrozone; the other nine were in the central, southern, central-southern macrozones and the Metropolitan Region. This information reveals the difficulties that instructors have in accessing cadaver material, especially in the extreme areas, limiting the possibility of using cadaver preparations for morphological study. At the moment there is consensus that cadaver study is a unique opportunity to confirm empirically the state of the organs and body systems (Inzunza, 2008), so it is understood that the lack of this material represents a disadvantage to accessing the knowledge. This situation could be seen as an opportunity, for example for the scientific societies to take on the task of organizing cadaver donation programs to facilitate this access.

From this, it is deduced that a morphologist's geographical location could affect their job opportunities, continuity of morphological studies and chances to access cadaver material.

In relation to gender, it was observed that men represented $65.89 \%$ and women $34.11 \%$ (Fig. 1A). The "UCHILE Institutional Directory 2019" (Universidad de Chile) describes that of all the academics $63.4 \%$ were men and $36.6 \%$ were women, similar to what was described by Cruz-Boullosa \& Bernui (2019), who reported that the distribution by gender in Peru is $71.4 \%$ men and $28.6 \%$ women. The same scenario was mentioned by Cruz de Urioste (2016), who described the educational reality in Bolivian universities, indicating that $72 \%$ were men and 28 $\%$ women. The similarity of these data suggests that the gender gap in the university environment is not only a national reality, but also a Latin American one. These data agree with Bertoni (1998) regarding women's participation in the workforce in recent decades, and with Cruz de Urioste, who notes that "the university is a male domain". In Chile, although there is no substantial evidence of the actual ratio of men to women, encouraging more women to taken on morphology teaching would help foster a gender-positive attitude among academics, students and graduates.One interesting aspect is that in Chile university professors are often considered opinion leaders, belonging to a select group of people held in high social esteem, which is why the emphasis on equality and diversity within university activity is not only a legal imperative, but may also be considered a moral imperative. At present, although there is extensive literature on gender issues and sociology of medicine, there is little information available on these aspects in morphology.

Limitations and recommendations for future studies. Generalization of the results was considered because a non-probabilistic sample was used, but it had the advantage of including a large number of participants. In particular, there was selection bias, since participation was voluntary. The survey sample size did not represent the morphology teachers in all Chilean universities; therefore, the results cannot be generalized. However, instructors were contacted in each of the 51 Chilean universities that taught some of the subjects related to morphology, obtaining a response of $46 \%$ of the instructors contacted. This result, although sufficient, was below expectations. Studies that evaluated the response rates of academic surveys demonstrated that a typical rate is $50 \%(\mathrm{SD} \pm 20 \%)$ and of those who represent an organization or senior management, such as a dean or department head, $36 \%$ (SD $\pm 19 \%$ ) (Baruch, 1999; Baruch $\&$ Holtom, 2008). Although our response rate was moderate, it is within an acceptable range for the academic population. On the other hand, we think that the response rate should not be considered as the only criterion to evaluate the representative nature of this study. The reader must consider other factors such as the heterogeneity of the collected data, which represent teacher profiles in each of the macrozones and Metropolitan Region; profiles that perform in anatomy, histology, neuroanatomy and embryology in $\mathrm{CRUCH}$ universities, private universities included and not included in the Single Admission System; professionals who presented different years of academic experience and which were related to the education, medical, veterinary and biological sciences. Moreover, the cross-sectional nature of the study did not enable comparison with previous studies. Finally, no variables related to the impact of the pandemic were included, since the survey was applied during a health crisis.

Having established a baseline level for what is an acceptable and reasonable response rate regarding the teaching profile, there are two important questions that must be answered in subsequent studies, particularly referring to 
the education of morphology in Chile: a) how important is teaching and learning in the morphological discipline? In that context we believe it is relevant to examine the syllabi, the manner and the quality of morphological teaching, how it is taught and the infrastructure in which it is taught, and $b$ ) which morphology teaching, learning and evaluation methods are effective? As the curriculum changes, the syllabi must maximize the effectiveness of morphological teaching, the resources and the new technologies available and, which is more important, the memory and application of anatomical knowledge in future professional practice.

Finally, we consider that this study reflects the reality of morphological sciences and the professionals who teach them in Chile. Also, we hope that the information provided is of use for universities and scientific societies, both national and international, and becomes a tool to promote and develop morphology in the future.

\section{CONCLUSION}

The profile of the morphology teacher in Chile is mainly men, dedicated essentially to teaching, with a majority with experience between 5 and 10 years. Professional trends are observed related to the disciplinary area of dedication: anatomy is taught mainly by physiotherapists and dentists, whereas in histology and embryology there is mixed professional group, with a predominance of biologists and veterinarians. Among these instructors, those with a master's degree predominate, highlighting broad graduate training, mainly certificates. Approximately half work full time, with the remaining group working half days or by the hour. Regardless of the hours worked, the workday is dedicated mainly to teaching. With respect to the geographical distribution of the morphologists, there is an evident relation to the location of the university academic offering, with the largest number of academics with graduate degrees being concentrated in the Metropolitan Region, demonstrating an unequal distribution when academic degree is associated with geographical distribution. All this suggests a multidisciplinary academic profile, which reveals the mainstreaming of morphology teaching in Chile in 2020 .

\section{ACKNOWLEDGEMENTS}

The authors with to thank sincerely all the teachers who answered the survey. This work could not have been done without their valuable collaboration.
FARFÁN, E.; CÁRDENAS, J.; ESPINOZA-NAVARRO, O.; LIZANA, P. A.; PACHECO, J. ; SALINAS, P.; RIVEROS, A. \& VILLARROEL, M. Perfil de los docentes de morfología en universidades chilenas. Int. J. Morphol., 39(6):1615-1624, 2021.

RESUMEN: La docencia universitaria en Chile se ha visto influenciada en las últimas décadas por modificaciones del sistema educativo, las cuales generaron un incremento de universidades y oferta académica y, por ende, demanda de nuevos docentes. La enseñanza de las ciencias morfológicas no ha quedado exenta de estos cambios, teniendo que enfrentar la necesidad de nuevos docentes requeridos para suplir la creciente oferta de programas que incluyen a la anatomía, embriología e histología. El objetivo fue conocer el perfil de los académicos que realizaron docencia de morfología en Chile el año 2020. Se aplicó una encuesta online voluntaria a 213 académicos universitarios de morfología, en la cual se recopiló información sobre formación profesional, académica, distribución geográfica, género, perfeccionamiento académico y situación laboral. Los resultados, en general, muestran que el $65,9 \%$ de los docentes eran hombres y un $35,1 \%$ mujeres, los que en su mayoría $(34,6 \%)$ tenían entre 5 y 10 años vinculados a la morfología y donde prevalecía el grado académico de magíster $(53,27 \%)$. En el área de la anatomía el $46 \%$ de los docentes correspondió a kinesiólogos y el 24,6\% a odontólogos, mientras que, en las áreas de histología y embriología el grupo fue misceláneo. En el ámbito laboral el 49,06 \% declaró tener jornada completa, destinada principalmente a la docencia. El 41,31\% de los docentes se concentró en la Región Metropolitana. No hubo asociación entre género y formación de postgrado, máximo grado académico alcanzado, tipo de jornada y perfil académico, pero si hubo por área disciplinar. Se concluye que los docentes de morfología en Chile pertenecen a un amplio espectro de profesionales dedicados a distintas áreas disciplinares, con formación de magíster y/o especialización, ubicados principalmente en la Región Metropolitana. Este perfil multidisciplinar demuestra la transversalidad de la docencia morfológica en Chile.

PALABRAS CLAVE: Docencia; Morfología; Universidad; Chile.

\section{REFERENCES}

Agencia Nacional de Investigación y Desarrollo (ANID). 2021. Available from: https://ayuda.anid.cl/hc/es/articles/360048066052--Cu \%C3 $\%$ A1les-son-las-Macrozonas-del-Ministerio-de-Ciencia-Tecnolog \%C3 $\% \mathrm{ADa}$-Conocimiento-e-Innovaci \%C3 \%B3n-

Ansmann, L.; Flickinger, T. E.; Barello, S.; Kunneman, M.; Mantwill, S.; Quilligan, S.; Zanini, C. \& Aelbrecht, K. Career development for early career academics: benefits of networking and the role of professional societies. Patient Educ. Couns., 97(1):132-4, 2014.

Atanda, A. I. Mentoring and career growth of junior faculty in the University of Ibadan. J. Teach. Educ., 7(1):419-28, 2017.

Baruch, Y. \& Holtom, B. C. Survey response rate levels and trends in organizational research. Hum. Relat., 61:1139-60, 2008.

Baruch, Y. Response rate in academic studies-A comparative analysis. Hum. Relat., 52:421-38, 1999.

Bertoni, J. S. Fuerza laboral de la mujer en Chile: cifras y características. Rev. Latinoam. Enfermagem, 6(5):53-8, 1998. 
Cárdenas, V. J. \& Rodríguez, T. A. Chilean society of anatomy. The beginning. Int. J. Morphol., 36(3):1075-8, 2018.

Cárdenas, V. J. History of anatomy in Chile part II. The alma mater. Int. J. Morphol., 38(4):1074-89, 2020.

Cárdenas, V. J. History of anatomy in Chile. The beginnings. Int. J. Morphol., 35(3):958-63, 2017.

Carlson, B. M. Embryology in the medical curriculum. Anat. Rec., 269(2):89-98, 2002.

Consejo Nacional de Educación (CNED). Informe tendencias de estadísticas de educación superior por sexo. 2020. Available from: https:/ / w w w . c n e d . c $1 / \mathrm{s}$ i te s/de f a u $1 \mathrm{t} / \mathrm{f} \mathrm{i} 1 \mathrm{e}$ s $/$ 2020_informe_matricula_por_sexo_0.pdf

Cruz de Urioste, M. Estadística de género de las universidades de la ciudad de Santa Cruz de la Sierra. Rev. Aportes Com., 20:52-9, 2016.

Cruz-Boullosa, V. \& Bernui, I. Satisfacción laboral en docentes de la Facultad de Medicina de una Universidad Pública. An. Fac. Med., 80(4):494-7, 2019.

Cruz-Coke, R. Evolución de las universidades chilenas 1981-2004. Rev. Méd. Chile, 132(12):1543-9, 2004.

Departamento de Evaluación, Medición y Registro Educacional (DEMRE). Oferta definitiva de Carreras, vacantes y ponderaciones- proceso 2020. 2020. Available from: https://demre.cl/postulacion/ carreras-requisitos-y-ponderaciones-p2020/universidad-chile

Diamond, K. K.; Vasquez, C.; Borroni, C. \& Paredes, R. Exploring veterinary medicine students' experiences with team-based learning at the Universidad Andrés Bello. J. Vet. Med. Educ., 47(4):421-9, 2020.

Fraher, J. P. \& Evans, D. J. Training tomorrow's anatomists today: A partnership approach. Anat. Sci. Educ., 2(3):119-25, 2009.

Ganga, F. \& Felix, J. Sistemas de compensación e incentivos: opinión de rectores y miembros de los máximos cuerpos colegiados de las universidades chilenas. Gac. Lab., 18(1):57-85, 2012.

Heckathorn, D. Snowball versus respondent-driven sampling. Sociol. Methodol., 41(1):355-66, 2011.

Inzunza, O. Competencias Generales en Medicina, Rol de la Anatomía. Int. J. Morphol., 26(2):243-6, 2008.

Johnson, E. O.; Charchanti, A. V. \& Troupis, T. G. Modernization of an anatomy class: From conceptualization to implementation. A case for integrated multimodal-multidisciplinary teaching. Anat. Sci. Educ., 5(6):354-66, 2012.

Kagan, I. I. Traditions and peculiarities of clinical anatomy education in Russia. Clin. Anat., 15(2):152-6, 2002.

Kaplan, K. Professional societies: Come together. Nature, 502(7472):5813, 2013.

Khan, M. M. Assessment of anatomy curriculum for future clinicians at College of Medicine, King Saud University, Saudi Arabia. Pak. J. Med. Sci., 23:625-9, 2007.

Kramer, B.; Pather, N. \& Ihunwo, A. O. Anatomy: Spotlight on Africa. Anat. Sci. Educ., 1(3):111-8, 2008.

Lachman, N.; Christensen, K. N. \& Pawlina, W. Anatomy teaching assistants: Facilitating teaching skills for medical students through apprenticeship and mentoring. Med. Teach., 35(1):e919-25, 2013.

Levy, R. Postdoc mentorship can launch careers. Am. Sci., 102(6):41821, 2014.

Matyas, M. L.; Ruedi, E. A.; Engen, K. \& Chang, A. L. Life science professional societies expand undergraduate education efforts. $C B E$ Life Sci. Educ., 16(1):ar5, 2017.

Osorio, H.; Toro, J.C.; Schorwer, K.; Riveros, A. \& Cárdenas, J. Pioneers of a century of anatomical teaching in the city of concepción, Chile. Int. J. Morphol., 38(3):650-8, 2020.

Rodríguez, T. A. \& Cárdenas, V. J. The origins of the Society of Normal and Pathological Anatomy of Chile. Int. J. Morphol., 35(2):751-5, 2017.

Schaefer, A. F.; Wilson, A. B.; Barger, J. B.; Azim, H. M.; Brokaw, J. J. \& Brooks, W. S. What does a modern anatomist look like? Current trends in the training of Anatomy educators. Anat. Sci. Educ., 12(3):225-35, 2018.

Skopnik-Chicago, M.; Poblete-Cordero, K.; Zamora, N.; Bastías, R. \& Lizana, P. A. Comparison of haptic and biometric properties, bacterial load, and student perception of fixative solutions: formaldehyde versus Chilean conservative fixative solution with and without formaldehyde in pig kidneys. Anat. Sci. Educ., 2020. DOI: https:// www.doi.org/10.1002/ase.2042

Tiznado-Matzner, G.; Bucarey-Arriagada, S. \& Aravena, P.C. Journey through the reality of human anatomy laboratories of 12 chilean universities. Int. J. Morphol., 37(1):17-21, 2019.

Universidad de Chile. Anuario. Portal de Libros Electrónicos, 2019. Available from: https://libros.uchile.cl/files/presses/1/monographs/ 1146/submission/proof/54/index.html

Web of Science. 2021. Available from: https://www.webofknowledge.com

\section{Corresponding author: \\ Dr. Emilio Farfán Cabello \\ Departamento de Anatomía \\ Escuela de Medicina \\ Pontificia Universidad Católica de Chile \\ Av. Libertador Bernardo O'Higgins \#340 \\ Santiago \\ CHILE}

E-mail: efarfanc@uc.cl

Received: 20-07-2021

Accepted: 28-08-2021 